\title{
A NEW SPECIES OF THE GENUS HEXABATHYNELLA (SYNCARIDA, BATHYNELLACEA, PARABATHYNELLIDAE) FROM SPAIN
}

\author{
by
}

\author{
ANA ISABEL CAMACHO \\ Museo Nacional de Ciencias Naturales, Calle José Gutierrez Abascal 2, 28006-Madrid, Spain
}

\begin{abstract}
A new species of the genus Hexabathynella is described from Spain. It is the first time that this genus is found in this country. A rich material has been collected on the banks of the Jarama River (near Madrid) during every season of the year.

\section{RÉSUMÉ}

On décrit une nouvelle espèce de Hexabathynella, yenre nouveau pour l'Espagne. Un matériel riche a été récolté pendant toute l'année dans le sous-écoulement de Río Jarama, non loin de Madrid.
\end{abstract}

\section{INTRODUCTION}

In Spain the first Syncarida were discovered by Professor R. Margalef (1951). He found an immature specimen (with 5 pairs of thoracopods) in the "Cueva de Genova" (Palma de Mallorca), and identified it as Parabathynella phreatica. In 1954 Delamare Debouteville \& Chappuis studied the specimen and concluded that is was a Parabathynella fagei. When Schminke (1973) created the genus Iberobathynella, for species from Portugal and the Oriental Pyrenees, the Spanish specimen was reallocated to this new genus. The same species was also found in the "Cueva de la Pileta" (Malaga) by Coiffait \& Vandel (1952) and studied by Delamare Deboutteville \& Chappuis, 1954.

Specimens found for the second time in the "Cueva de Genova" and "Cova de Can Sion"' (Mallorca) by Orghidan \& Tabaccaru in 1970 and 1971 were also attributed to this species.

In 1974 Comas i Navarro found some specimens in the "Cova del Infierno" (Asturias) which were studied by Serban \& Comas i Navarro (1978) and described as two new species: Iberobathynella asturiensis and I. espaniensis.

Until now, these three species were the only representatives of the family Parabathynellidae found in Spain.

In 1983 and 1984 while working on a project in the Jarama River (Madrid) we were able to collect many specimens of bathynellids from both the family Parabathynellidae and the family Bathynellidae.

The new species described in this paper belongs to the genus Hexabathynella, recorded for the first time in Spain.

\section{DESCRIPTION}

Hexabathynella nicoleiana n. sp. (Figs. 1-4)

Material examined. - Ten $\sigma^{\circ} \sigma$ and fourteen $\& \%$, collected in Talamanca del Jarama (UTM: 30TVL568105) and Torrelaguna (UTM: 30TVL563123) during the months of January, March, April, May, July, August, and September of 1983 and 1984.

The description of the species has been based on the study of 14 specimens that constitute the type series.

All specimens were dissected; one male being the holotype and one female the paratype. The drawings are based on the entire series.

Total length of the male: $1.13-1.25 \mathrm{~mm}$. Total length of the female: $0.72-0.99 \mathrm{~mm}$.

The body is elongate, almost cylindrical. Body segments widen and lengthen towards the posterior end.

The head is longer than wide and about as long as the first 4 thoracic segments (fig. 1).

Antennula (fig. 2: 1 and 2). Very thick, 6 segments that are considerably longer than the head. The male presents secondary sexual char- 


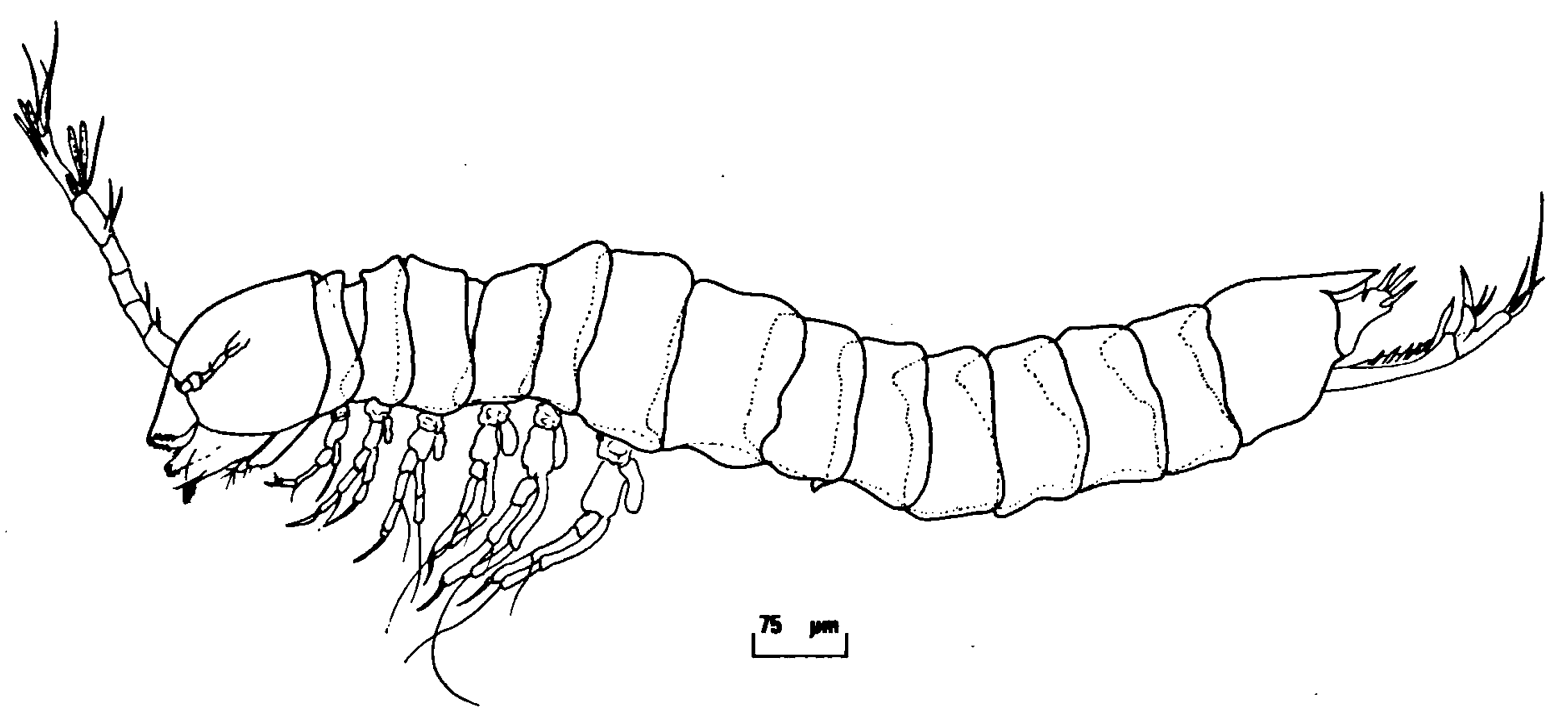

Fig. 1. Hexabathynella nicoleiana n. sp., habitus (female), lateral view.

acteristics. Segments 1 and 2 are thicker in the male than in the female and their setal formula is somewhat more complex. The antennal organ in the male is situated on segment 2 , on a protuberance of the inner distal angle. In the apical zone it bears some curved prolongations of equal lengths and with a rounded top. In the female this structure is replaced by two plumose setae. The male has also two ventromedial setae on segment 2. Segment 3 is similar in both sexes, with two setae on the outer margin, 2 ventromedial setae, and one seta on the inner margin which is shorter than the others. There is a small rudimentary endopodite with 3 setae. Segment 4 bears several simple setae. Segment 5 bears 3 aesthetes, typical of this genus, one seta on the inner margin, and two more ventral setae between the aesthetes. The last segment has 3 characteristic setae and 3 aesthetes inserted more proximally in a concavity of the outer margin.

Antenna (fig. 2: 3) consisting of 5 small segments curved backwards between segments 2 and 3 . The segments increase gradually in size and the last is rather large. Setal formula: $0+0 / 0+0 / 0+0 / 0+0 / 3$. The medial seta of the last segment is shorter than the others and of the lancet type, the others are of type a.
Labrum (fig. 2: 4). Eight large, uniform teeth between two small pointed and curved teeth on either end.

Mandible (fig. 2: $5 a$ and 5b). Four distal teeth on the pars incisiva, one of which stronger. One large and triangular proximal tooth and one long, narrow tooth between the pars incisiva and the "Borstenlobus". The "Borstenlobus" bears 4 setae. The 1segmented palp does not exceed the distal end of the mandible.

Maxillula (fig. 2: $6 \mathrm{a}$ and 6b). Twosegmented, proximal endite with 3 serrate spines and distal endite with 3 strong, curved subterminal setae and 4 strong spines of which only the proximal spine is ciliated.

Maxilla (fig. 2: $7 \mathrm{a}$ and 7b). Threesegmented; proximal segment with 2 setae; second segment with 3 long and 1 short setae; third segment well-armed with 13 long and short setae, the shortest of which tends to be subterminal; 3 curved terminal setae are longer.

Thoracopods 1-6 ( $\%, \sigma^{\circ}$ ) (fig. 3: 1, 2, 3, 4, 5 and 6$)$. Six pairs of thoracopods, the seventh is missing. Th1-Th4 gradually increase in length. Th4-Th6 are about equal in length. Th1 is rather short, lacking an epipodite; exopodite 1-segmented with 1 long seta and ter- 


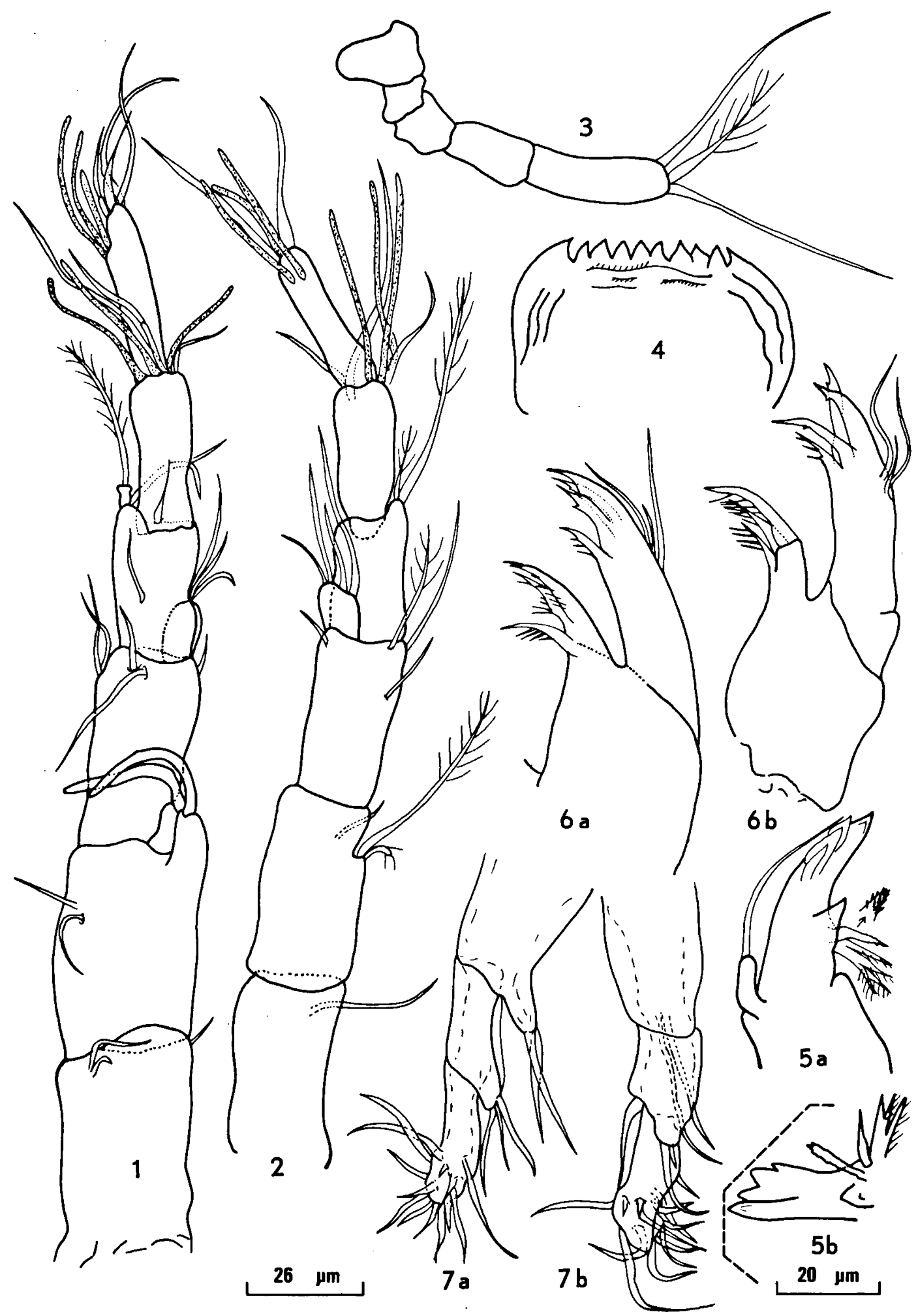

Fig. 2. Hexabathynella nicoleiana n. sp.: 1, antennula (male); 2, antennula (female); 3, antenna (male); 4, labrum; 5 a and $5 \mathrm{~b}$, mandible; $6 \mathrm{a}$ and $6 \mathrm{~b}$, maxillula; $7 \mathrm{a}$ and $7 \mathrm{~b}$, maxilla. 
A. I. GAMACHO - HEXABATHYNELLA NICOLEIANA N. SP.

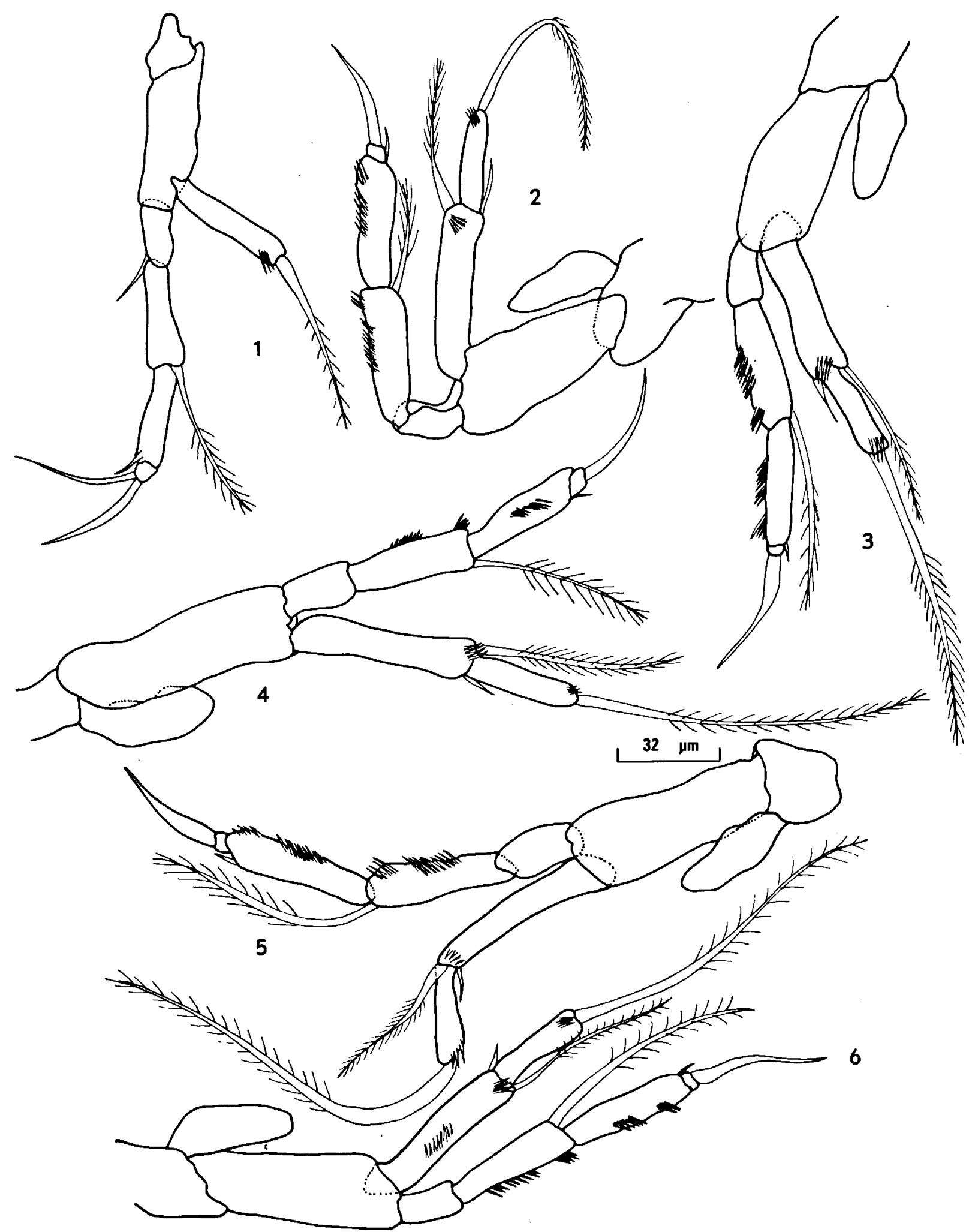

Fig. 3. Hexabathynella nicoleiana n. sp., thoracopods (male). 1, Th1; 2, Th2; 3, Th3; 4, Th4; 5, Th5; 6, Th6. 
minal ctenidia. Endopodite 4-segmented, segments 1-3 with distal setae, the second of which is plumose; last segment very small, with 2 strong claws. None of the segments have ctenidia. Th2-Th6 identical, with elongated epipodites, 2-segmented exopodites with 2 setae on the first segment, the larger of which is plumose and only one long, plumose terminal seta on the second segment. Ctenidia present in the apical part of each segment. The endopodite consists of 4 segments, increasing gradually in size from the first to the third, the fourth is very small. The first segment lacks setae, the second bears one long plumose seta, the third has a small distal seta on the inner margin, and the fourth ends in a strong claw. In the thoracopods $2-6$, segments 2 and 3 of the endopodite have 2 groups of ctenidia, the distal group of only a few elements and the proximal with up to 9 elements.

Thoracopod 8 ( $0^{*}$ ) (fig. 4: 5, 6, 7 and 8). Relatively large and massive in size. The basal segment of the protopodite protrudes over the inner distal margin and ends in a dentated crown of 8 teeth that could correspond with the toothed lobe of the genus Iberobathynella. The outer lobe ends in a small claw. The basipodite is quadrangular and cleft, forming two free lobes between which a seta emerges from the exopodite which is not clearly individualized. The endopodite is elongated, shorter than the basipodite, and bears 2 thin setae of about the same length.

Pleotelson (fig. 4: 1 and 3). One lateral seta close to the anal operculum. The anal operculum is very pronounced, slightly shorter than the furca. The furcal organ has 3 forked spines at its end, with fine lateral cilia, and 2 dorsal setae of different length on its dorsal surface.

Uropod (fig. 4: 2). Sympod 4 times longer than wide, with 6-7 spines, of which the distal one is thicker and almost twice longer than the others. The endopod is almost half as long as the sympod and ends into a pointed tooth with 2 setae, one long and one short, inserted half way its outer margin. The exopodite is half as long as the sympod and ends into 1 large plumose seta and 2 shorter setae, one of which plumose.
The female. - The body of the female is identical to that of the male, except in size, tending to be longer and thicker than in male. Antenna 1 lacks the antennal organ. Uropod with 5-6 spines, fewer than in male. Thoracopod 8 (fig. 4: 4) consists of a small plate from which 2 pointed processes arise.

Variability. - All the specimens observed look similar, except in number of spines in the uropod, that fluctuates between 6 and 8 in male and 5 and 6 in female. Small size differences have also been observed but none of them are relevant.

\section{DISCUSSION}

Hexabathynella nicoleiana $\mathrm{n}$. sp. presents several unique characteristics that separate it completely from the remaining species in the genus: (1) Anal operculum almost as long as the furca and ending into a point (in the rest of the species it is rounded). (2) Antennal organ formed by two protuberances from which two long, elongated, curved, prolongations with rounded tops and equal in length arise. (3) The spines on the sympod of the uropod are numerous and of equal size and shape (except the most distal). (4) The presence of 2 groups of ctenidia on segments 2 and 3 of the endopod of all the thoracopods, the proximal group consisting of a large number of elements (up to 9) but the distal one similar to those of the other species. (5) The morphology of thoracopod 8 in the male.

The first characteristic links the new species to Hexabathynella szidati (Noodt, 1965), to which it also resembles in other ways. But it clearly differs from $H$. szidati in the number of teeth on the labrum and, most of all, in the presence of epipodites on Th1 in $H$. szidati, as well as in the shape and size of the lobes of Th8 in male and other less significant differences.

It is also similar to $H$. minuta (Noodt \& Galhano, 1969), but there is a considerable difference in size. $H$. minuta does not exceed 0.75 $\mathrm{mm}$, while $H$. nicoleiana is among the largest species in the genus. Differences also exist in the shape of the antennal organ, the modifica- 


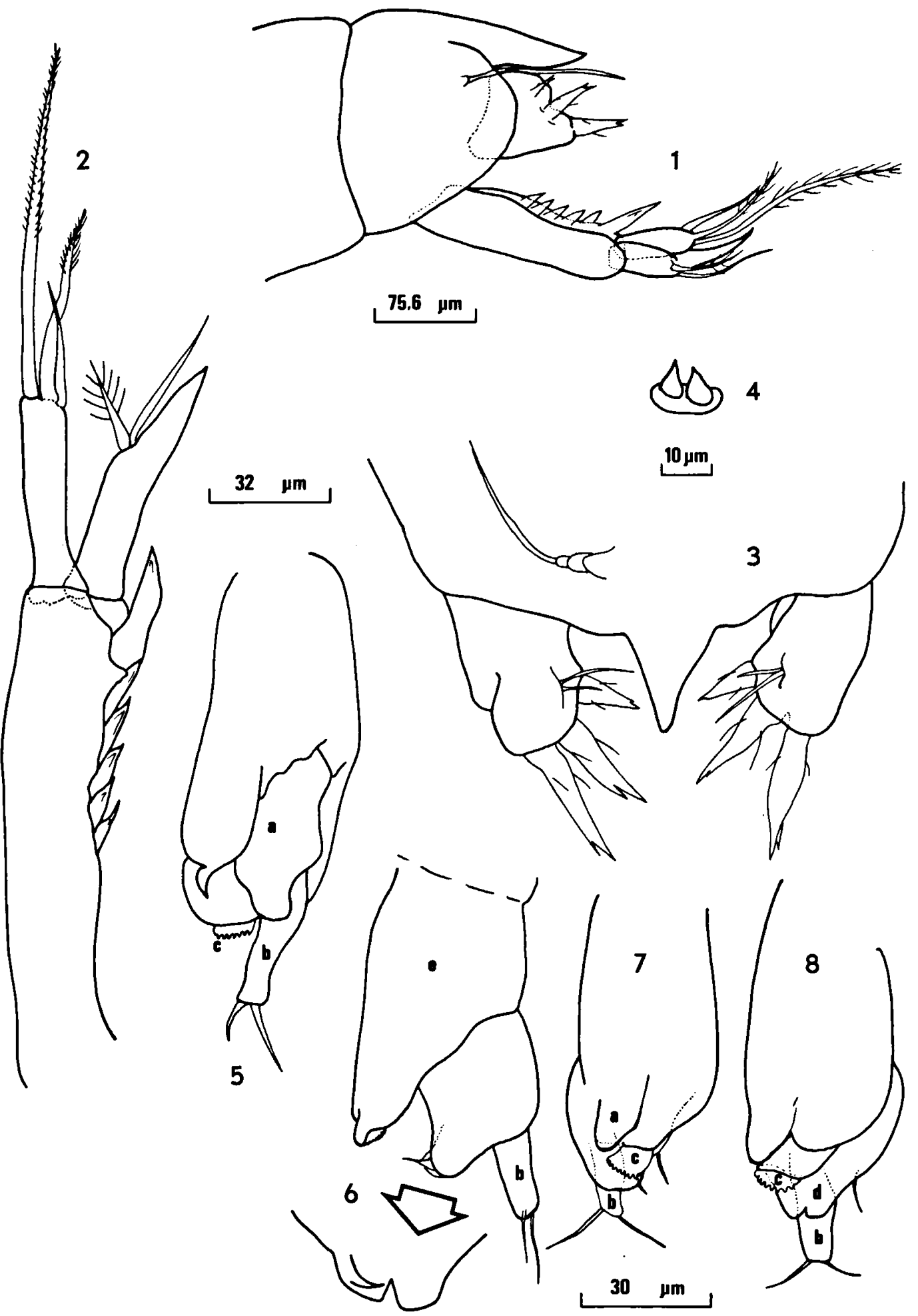

Fig. 4. Hexabathynella nicoleiana $\mathrm{n}$. sp.: 1 , pleotelson; 2 , uropod; 3 , furca; 4 , thoracopod 8 , female; $5,6,7,8$, thoracopod 8, male (different views), (a) external lobe; (b) endopodite; (c) toothed lobe; (d) exopodite; (e) basal segment. 
tion of the proximal tooth of the pars incisiva, the number of spines on the sympod of uropod 3 , the lobes and spines of Th8 in the male, the size and shape of the anal operculum, and the setae and teeth of $\mathrm{Mx}$.

The similarity to $H$. pauliani (Delamare Deboutteville, 1953) and $H$. aotearoae Schminke, 1973 , is slightly greater than that to $H$. halophila Schminke, 1972, and $H$. decora Schminke, 1973; $H$. knoeffleri (Coineau, 1965) and $H$. hebrica (Cvetkov \& Petrova, 1964) are the most different.

$H$. nicoleiana is part of a group of species consisting of $H$. minuta, $H$. knoeffleri, $H$. hebrica, $H$. nestica (Cvetkov, 1970), $H$. breviappendiculata (Cvetkov, 1970) and $H$. longiappendiculata (Cvetkov, 1970), fundamentally because of the presence of a single seta on the pleotelson, the absence of setae below the proximal tooth of the terminal endite of $M \times 1$, and the presence of forked spines on the furca.

It seems premature to attempt to establish the relationship between $H$. nicoleiana and the rest of the species of the genus Hexabathynella. Since Schminke's analysis (1973), the methodology of phylogenetic inference has evolved considerably, which, along with the discovery of new species since then, demands a complete revision of the phylogenetic outline. Furthermore, new biogeographic analysis models (Nelson \& Platnick, 1978) make it feasible to extend the interpretation to the global distribution of the group. In conclusion we believe this revision should be postponed temporarily.

Derivatio nominis. - This species is dedicated to Dr. Nicole Coineau, who has initiated me in the systematics of this particular group of crustaceans.

\section{DISTRIBUTION OF THE GENUS HEXA- BATHYNELLA SCHMINKE, 1972a}

Syn.: Parabathynella Chappuis, 1926, partim.

The distribution of the 13 known species is as follows:

H. pauliani (Delamare Debouteville, 1953)

Madagascar
H. aotearoae Schminke, 1973

New Zealand

H. hebrica (Cvetkov \& Petrova, 1964)

Bulgaria

H. knoeffleri (Coineau, 1965)

Corsica

H. szidati (Noodt, 1965)

Argentina

H. minuta (Noodt \& Galhano, 1969)

Portugal

H. halophila Schminke, 1972

Australia

H. paranaensis (Jakobi, 1972)

Brazil

H. decora Schminke, 1973

Australia

H. tenera (Cvetkov, 1968)

The Balkans and Bulgaria

H. nestica (Cvetkov, 1970)

The Balkans

H. longiappendiculata (Cvetkov, 1970)

Bulgaria

H. breviappendiculata (Cvetkov, 1970)

Bulgaria

H. nicoleiana n. sp.

Spain

The map (fig. 5) shows the geographic location of the species. The irregular distribution pattern of the Syncarida appears to be due, in part, to lack of research done in the interstitial medium. Therefore, although the genus Hexabathynella was previously found in Portugal, this is the first time that it is recorded from Spain in spite of its abundance, as can be seen from our samples. However, its absence in relatively well-sampled areas in north-western Europe remains to be explained.

\section{ACKNOWLEDGEMENTS}

I am grateful to Mme. N. Coineau for the generous guidance through all the phases of the description of this new species; to Dr. A. Garcia-Valdecasas, who has directed and oriented my work, to my colleagues at the Museo Nacional de Ciencias Naturales de Madrid who, on numerous occasions, have accompanied me on field trips to gather material, and to C. Puch for his help in preparing the drawings, as well as for his moral support. Rosemary Amils has kindly translated the manuscript. 


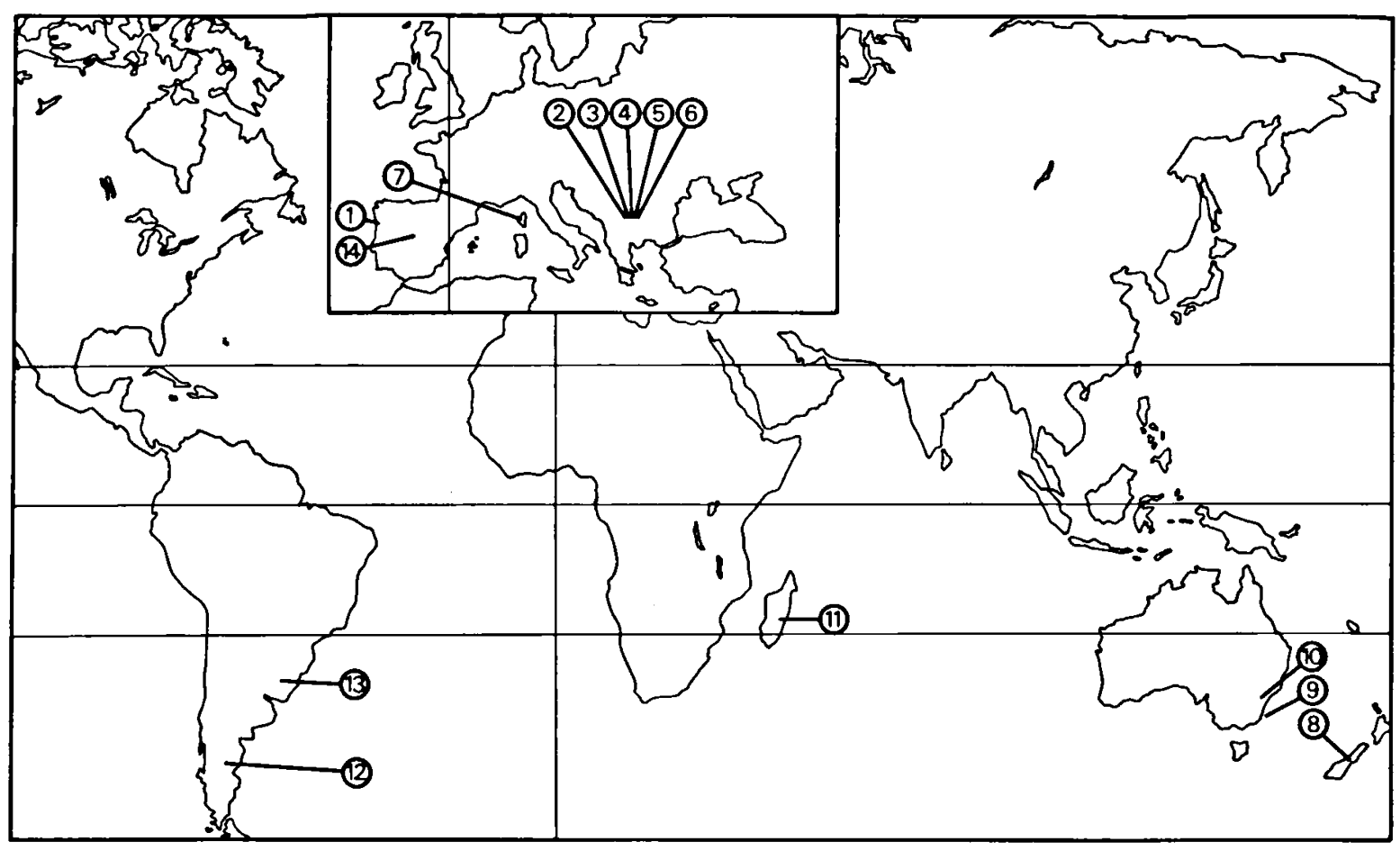

Fig. 5. Distribution of members of Hexabathynella. $1, H$. minuta; $2, H$. hebrica; $3, H$. tenera; $4, H$. nestica; 5, $H$. longiappendiculata; 6, H. breviappendiculata; 7, H. knoeffleri; $8, H$. aotearoae; 9, H. halophila; 10, H. decora; 11, H. pauliani; $12, H$. szidati; 13, H. paranaensis; 14, H. nicoleiana n. sp.

\section{REFERENCES}

Coineau, N., 1965. Recherches sur la faune des îles méditerranéennes. I. Le genre Parabathynella (Crust. Syncar.) en Corse. Vie Milieu, 15 (4): “1964": 993-1005.

Cvetrov, L., 1968. Nouvelle forme du groupe de Parabathynella hebrica Cvetkov \& Petrova. C.r. Acad. bulg. Sci., 21 (1): 55-58.

——, 1970a. Deux nouvelles espèces de Parabathynella (Crust. Bathynellacea) en Bulgarie du sud. C. r. Acad. bulg. Sci., 23 (5): 575-578.

- , 1970b. Parabathynella longiappendiculata n. sp. La cinquième nouvelle espèce de Parabathynella en Bulgarie du sud. C. r. Acad. bulg. Sci., 23 (11): 1409-1411.

Cvetkov, L. A. Petrova, 1964. Un nouveau représentant des Syncarides, Parabathynella hebrica n. sp. Izv. zool. Inst. Sofiya, 16: 191-200.

Delamare-Deboutteville, $\mathrm{Cl}$., 1953. Une espèce nouvelle de Parabathynelle à Madagascar: Parabathynella pauliani, n.sp. Diagnose préliminaire. Vie Milieu, 4 (4): 748.

Delamare-Deboutteville, Cl. \& P. A. Chappuis, 1954.
Les Bathynella de France et d'Espagne. Archs. Zool. exp. gén., 91 (1): 51-102.

Delamare-Deboutteville, Cl. * R. Paulian, 1954. Recherches sur la faune interstitielle des sédiments marins et d'eau douce à Madagascar. V. Découverte de l'ordre des Syncarides. Description de trois espèces nouvelles. Mém. Inst. sci. Madagascar, (A) 9: 75-89.

Margalef, R., 1951. Un sincárido del género Parabathynella en las Baleares. Publnes. Inst. Biol. apl., Barcelona, 8: 151-153.

Nelson, G. N. I. Platnick, 1978. The perils of plesiomorphy: widespread taxa, dispersal, and phenetic biogeography. Syst. Zool., 27: 474-477.

Noodt, W., 1965. Crustacea subterranea aus Argentinien. Beitr. neotrop. Fauna, 4 (2): 84-129.

Noodt, W. M. H. Galmano, 1969. Studien an Crustacea subterranea (Isopoda, Syncarida, Copepoda) aus dem Norden Portugals. Publicações Inst. Zool. Dr. A. Nobre, 107: 9-75.

Schminke, H. K., 1972. Hexabathynella halophila gen. n. sp. n., und die Frage nach der marinen Abkunft der Bathynellacea (Crustacea, Malacostraca). Mar. Biol., 15: 282-287. 
1973. Evolution, System und Verbreitungsgeschichte der Familie Parabathynellidae (Bathynellacea, Malacostraca). Mikrofauna Meeresbodens, 24: 1-192.

Serban, E. J. Comas i Navarro, 1978. Contribution à la connaissance du genre Iberobathynella Schminke: I. asturiensis n. sp. et I. espaniensis n. sp., nouvelles espèces d'Espagne (Bathynellacea, Parabathynellidae). Trav. Inst. Spéol. Emile Racovitza, 17: 13-37.

First draft received: 11 April 1985

Final draft received: 28 May 1985 